\title{
Revision of the supposed Triassic, in fact Silurian genus Triadophyllum Weissermel, 1925 (Anthozoa, Rugosa)
}

\author{
Dieter Weyer* \\ Museum für Naturkunde der Humboldt-Universität zu Berlin, Invalidenstraße 43, D-10115 Berlin, Germany
}

Received 10 December 2006, accepted 14 February 2007

Published 1 August 2007

With 7 figures

Key words: Rugosa, taxonomy, Silurian, Pleistocene erratic boulder, Germany.

\begin{abstract}
The only existing type specimen of Triadophyllum posthumum Weissermel, 1925 is not a Middle Triassic (middle Anisian, Pelsonian) Scleractinia, but a Silurian Rugosa collected from a Pleistocene erratic boulder of Baltoscandian origin. First serial cross sections demonstrate a synonymy of Triadophyllum Weissermel, 1925 with the worldwide distributed ahermatypic genus Palaeocyathus Foerste, 1888 (including also Enterolasma Simpson, 1900) known from Llandoverian/Wenlockian - Eifelian times. The species Palaeocyathus posthumus as well as the genus are still unknown in the classical Silurian sequences of Gotland and Estonia, which may be the possible origin of the glacial drift. At present, a more precise age determination within the Llandoverian, Wenlockian, or Ludlovian can not be achieved. The nearest certain occurrence of the genus is the early Wenlockian Palaeocyathus conicus (Bul'vanker, 1952) of Podolia (Ukraine), situated likewise on the southwestern margin of the ancient Baltoscandian shield; other records such as the Ludlovian Palaeocyathus bohemicus (Počta, 1902) from the Barrandian (Czech Republic) and Palaeocyathus radiatus (Münster, 1839) from Upper Franconia (Saxothuringia, Germany) are more distant on Gondwana-derived terranes.
\end{abstract}

Schlüsselwörter: Rugosa, Taxonomie, Silur, Pleistozän-Geschiebe, Deutschland.

\section{Zusammenfassung}

Das allein existierende Holotypus-Polypar von Triadophyllum posthumum Weissermel, 1925 ist kein Scleractinia-Vertreter der Mittel-Trias (mittleres Anis, Pelson), sondern ein silurisches Rugosa-Taxon, das aus einem Pleistozän-Geschiebe baltoskandischen Ursprungs gesammelt wurde. Eine erste Querschliffserie belegt die Synonymie von Triadophyllum Weissermel, 1925 mit dem weltweit verbreiteten ahermatypischen Genus Palaeocyathus Foerste, 1888 (einschließlich Enterolasma Simpson, 1900), das aus dem Zeitraum Llandovery/Wenlock - Eifel bekannt ist. Die Art Palaeocyathus posthumus und auch das Genus wurden in den klassischen Silur-Schichtfolgen von Gotland und Estland noch nicht gefunden, die als Herkunftsgebiete der glazialen Drift in Betracht kommen. Momentan lässt sich keine präzisere Altersbestimmung innerhalb des Llandovery, Wenlock oder Ludlow erreichen. Das nächste Vorkommen der Gattung, das ebenfalls am SW-Rand des alten Baltoskandischen Schildes liegt, ist Palaeocyathus conicus (Bul'vanker, 1952) im unteren Wenlock von Podolien (Ukraine). Andere Nachweise wie Palaeocyathus bohemicus (Počta, 1902) aus dem Ludlov des Barrandium (Tschechische Republik) und Palaeocyathus radiatus (Münster, 1839) aus dem Ludlow von Oberfranken (Saxothuringikum, Deutschland) gehören zu primär entfernteren Terranes, die von Gondwana herkommen.

\footnotetext{
*E-mail: dieter.weyer@t-online.de
} 


\section{Introduction}

Middle Anisian (Pelsonian) corals from the PeriTethyan German-Polish Lower Muschelkalk Subgroup represent the first real Scleractinia ("Hexacorallia") after the complete extinction of all Rugosa at the Permian-Triassic boundary event (top Dorashamian or Changhsingian) and after the well-known worldwide gap of any skeleton-bearing Anthozoa in the first $7 \mathrm{Ma}$ of Early Triassic times (Indusian, Olenekian, basal Anisian).

Such a classification excludes the Pachythecalidae Cuif, 1975 (also Cuif 1977) = Hexanthiniaria Montanaro-Gallitelli, 1976, which really might become a separate taxon of equal rank as Rugosa and Scleractinia; and neglects for the moment some curious Middle Permian problematical taxa, socalled "scleractiniomorphs" (Ezaki 1997, 1998, 2000; Roniewicz et al. 2003; Stanley 2003) like Houchangocyathus Ezaki, 2000, and Numidiaphyllum Flügel, 1976 (Order Numidiaphyllida in Scrutton 1997, of equal rank as Rugosa and Scleractinia).

The much reduced time calibration for the outstanding early Triassic absence of skeletonized corals throughout the world follows Menning et al. (2005), in contrast to former assumptions such as the $14 \mathrm{Ma}$ of Roniewicz et al. (2003) or Stanley (2003) which originated obviously from the older, now abandoned time scales of Harland (1964) and Odin (1994).

This "fauna" - often only extremely rare and badly preserved single individuals of very few species - had been monographed by Weissermel (1925), with main revisions of Morycowa (1988). In those days (Weissermel 1925, 1927, 1928, 1936: 235; also Koker 1924: 27) some Scleractinian taxa ("Coelocoenia" = Koilocoenia, Pinacophyllum) were classified as Rugosa following Frech (1890), and Volz (1896). The newly proposed monotypic genus Triadophyllum Weissermel, 1925, based on one specimen from the Pelsonian (level of the "Terebratula" bed within the Schaumkalk zone, Middle Anisian) of Rüdersdorf quarry SE of Berlin, was also included: its author placed the taxon in the family Petraiidae (obviously in the sense of Počta 1902).

Later, additional representatives of Triadophyllum were published by Kolosváry (1958: 238, pl. $1 /$ 1-10, pl. 2/11-15, pl. 3/17-19 - Triadophyllum sp., and 1966, also in Balogh 1964: 633, fig. 47) from the Anisian of the Bükk Mountains in northern Hungary, and by Il'ina (1970) from the Ladinian/Karnian of the southeastern Pamir Mountains in Tadzhikistan. At present, these records are rather doubtful and indeterminate (according to the opinion of Il'ina 1984: 55 - requiring better preserved materials from both localities for a future revision).
The genus Triadophyllum Weissermel, 1925 then became - without any restudy - a member of the Scleractinia: Alloiteau (1952: 656 - within his new family Conophylliidae; accepted by Bendukidse \& Chikovani 1962: 407), Wells (1956: F378 - within the family Procyclolitidae Vaughan \& Wells, 1943), Krasnov (1970: 25, fig. 1). In the following period of more intensive Triassic coral revisions (mainly using also septal microstructures for refined and phylogenetic systematics), Triadophyllum was reasonably left out of consideration by Cuif (1977: 269, in his review of the Procyclolitidae) because of the insufficient primary diagnosis and lack of new records.

In the meantime (1977), I had started the reinvestigation of the holotype of Triadophyllum posthumum Weissermel, 1925. The results were amply discussed with the late Tamara Gennad'evna Il'ina (1924-2003) from Moscow, and she (Il'ina 1984: 55) published a preliminary note that this curious coral is definitely not a Scleractinian Triassic taxon, but a normal member of the Rugosa occurring in a Pleistocene erratic boulder of Silurian age. The details of this revision are presented here to abandon for ever any interpretation of the genus as belonging to the Mesozoic Scleractinia.

My opinion (at first based only on sediment preservation and on some experience with Palaeozoic erratic boulders, but later also influenced by the assignment to Palaeocyathus) opposes any Triassic interpretation - in full agreement with the advice (see appendix) of the late Walter Neben (1901-1971) who had explained me the stratigraphic mistake and the Silurian age already in 1965. The well preserved calcitic coral skeleton externally covered by some Bryozoa and a small favositid Tabulata (Fig. 1A, G) is definitive. True Triassic corals (with a primarily aragonitic skeleton) from Lower Muschelkalk beds never demonstrate such an excellent preservation (compare Fig. 7).

Being a Pleistocene erratic boulder of Baltoscandian origin (transported by continental ice drift from Sweden, especially the island of Gotland, or Estonia, and the bottom of the Baltic Sea in between), such corals could be either Ordovician or Silurian. But both lithology and taxonomy exclude an Ordovician age - it is not a coral from the Viruan (Macrourus Limestone, Rakvere/Nabala Limestones) or the Haruan ("Lyckholm" Limestones $=$ Vormsi and Pirgu substages, Porkuni Limestone), when compared with plenty of such material available to me. Hence, for the moment, the complete Silurian (Llandoverian, Wenlockian, Ludlovian, questionably also Pridolian) might be the possible age for Triadophyllum posthumum Weissermel, 1925; any more precise biostratigraphic zonation must await records of the same species in dated outcrops of Gotland or Estonia. 


\section{Redescription of "Triadophyllum" posthumum Weissermel, 1925}

Superorder Rugosa Milne-Edwards \& Haime, 1850 Order Stauriida Verrill, 1865

? Suborder Streptelasmatina Wedekind, 1927

? Family Streptelasmatidae Nicholson, 1889

\section{Subfamily Enterolasmatinae Hill, 1981}

The subfamily (Llandoverian-Emsian/Eiflian) is accepted basically in the sense of Hill (1981), but with only two genera for the moment: Palaeocyathus Foerste, 1888 (including as synonyms Enterolasma Simpson, 1900, Triadophyllum Weissermel, 1925, Orthopaterophyllum Nikolaeva in Bul'vanker, 1952, and probably also Paterophyllum Počta, 1902), and Soshkinolites Zheltonogova, 1963. A previous classification as Densiphyllidae Dybowski, 1873 (Weyer 1974 and McLean 1976 - together with Rhegmaphyllum Wedekind, 1927) might be viable too, but requires revision of Densiphyllum Dybowski, 1873 from the Rhuddanian of Estonia. Previously Kullmann (1965: 143) mentioned the close relationship towards Rhegmaphyllum, which differs from Palaeocyathus only by its shortened cardinal septum with a fossula.

Originally, the subfamily was included in the suborder Streptelasmatina. However, the diagnostic criterion for this assignment, the peculiar axial synapticulae, which occur in a similar way also in the Ditoecholasmatidae Sutherland, 1965, might have developed twice and independently during phylogeny. The latter family is perhaps closer to the suborder Cyathaxoniina Spasskiy, 1977 ("Metriophyllina Spasskiy, 1965" sensu Hill 1981), as a subfamily of Cyathaxoniidae Milne-Edwards \& Haime, 1850 aside of the Laccophyllinae Grabau, 1928.

Even Sutherland (1965: 35) united in his new family Ditoecholasma Simpson, 1900 and "Saucrophyllum Philip, 1962". The latter is considered to be partly a synonym of Laccophyllum Simpson, 1900 [the type species Laccophyllum pocillum (Philip, 1962)], and a related separate genus Sutherlandinia Weyer, 1972 [Saucrophyllum arbucklense Sutherland, $1965=$ Sutherlandinia petaloides (Ball \& Grove, 1940)]. Also Stumm (1949: 7) preferred the "metriophyllid" rather than "streptelasmatid" relationships of Enterolasma.

\section{Palaeocyathus Foerste, 1888}

The provisionally proposed synonymy (with Enterolasma Simpson, 1900, Paterophyllum Počta, 1902, and Orthopaterophyllum Nikolaeva in Bul'vanker, 1952), as suggested by Kullmann (1965), McLean (1976) and Hill (1981), has been expanded to include
Triadophyllum Weissermel, 1925. Necessary greater morphological knowledge could result in a more detailed taxonomy using some hitherto neglected features for subgeneric or generic subdivisions: ornament of septal flanks (smooth or spinous and flanged parallel to the distal septal margin), development of simple dissepiments (present near the calicular margin in an undescribed species of the Late Emsian from Morocco, and perhaps somewhat intermediate towards the Ludlovian Soshkinolites Zheltonogova, 1965, with well developed lonsdaleioid dissepiments), and appearance of a simple, everted axial structure (seen in a Pragian specimen from Thuringia).

The problematical status of Paterophyllum was mentioned by Oliver \& Galle (1971: 95); at present no sections of a lectotype of the type species Paterophyllum explanans Počta, 1902 are available. Interpretations such as those of Hill (1956: F257 questionable synonym of Metriophyllum MilneEdwards \& Haime, 1850) or Ivanovskiy (1960: 91 illegitimate vote for a changed genotype Paterophyllum consimile Počta, 1902, similar to Soshkina 1955: 121) can not be accepted. Protosyringaxon Ivanovskiy, 1963 (upper Llandoverian, Moyero River, Siberia, Russia) was said to be a probable synonym of Orthopaterophyllum (Ivanovskiy 1965: 59); however Hill (1981: F150) grouped the genus as a synonym of Axolasma Ivanovskiy, 1963 within the subfamily Streptelasmatinae, similar to Weyer (1973: 702, close to Densiphyllum Dybowski, 1873, pending a revision of that genus).

\section{Assigned Silurian species}

Cyathophyllum (Palaeocyathus) australe Foerste, 1888 (128, pl. 13/12-14), late Ludlovian (Rainbow Hill Marl Member), Yass region, New South Wales (Australia); revised by Hill (1940: 410, pl. 12/18,19,23) and McLean (1976: 182, fig. 2a-d, pl. 18/1-7).

Petraia radiata Münster, 1839 (42), Ludlovian (Elbersreuth "Orthoceratite" Limestone), Upper Franconia (Germany). Lectotype designation by Schindewolf (1931: 635, pl. 52/1); morphological revision of that specimen by Weyer (1980: 28, 36; 2001: 76). Palaeocyathus sp. (Weyer 1980: 34, figs $1 /$ 4, 6/1-12, pl. 1/4 - see Fig. 5) might be a juvenile specimen of this species.

Streptelasma bohemicum Počta, 1902 (156, figs 3-4, pl. 110/ 18-20), Ludlovian (Kopanina Formation), Barrandian area, Bohemia (Czech Republic). Compare Fig. 3-4.

Orthopaterophyllum conicum Bul'vanker, 1952 (7, pls 5/2, 6/ 5-7), early Wenlockian (Sheinwoodian, lower Kitaigorod Horizon, basal Demshin Beds); also Sytova (1975: 16, pl. 1/5).

Petraia waynensis Safford, 1869 (320, pl. 5/2a-h), Ludlovian (Brownsport and Henryhouse Formations), Tennessee and Oklahoma (USA), redescribed by Simpson (1900: 204, figs 13-15), Amsden (1949: 103, pl. 25/11-16), and Sutherland (1965: 22, pls 30/1-3, 31/4-5).

Streptelasma caliculum Hall, 1852 (111, pl. 32/1a-k), Wenlockian (upper Clinton Group), USA (New York, Maine, Indiana, Ohio) and Canada (Ontario); further descriptions in Lambe (1901: 113, pl. 7/4,4a-c), Grabau (1901: 137, fig. 29), and Brown (1909: 58, figs 11-26). Laub (1983: 21) doubted the generic assignment to Enterolasma - in 
spite of the thorough ontogenetic sections of Brown (1909) - because the type material has not been restudied.

Streptelasma radicans Hall, 1879 (106, pl. 5/1-4), late Wenlockian (Waldron Shale), Indiana and Tennessee (USA); repeated in Hall (1882: 226, pl. 4/1-4), hitherto not revised.

\section{Assigned Devonian species}

Streptelasma (Petraia) strictum Hall, 1874 (114), Lochkovian (Helderbergian), New York (USA); redescribed by Hall (1883: pl.1/1-10), Hall \& Simpson (1887: 1, pl. 1/1-10), Simpson (1900: 204, fig. 11-12), and Brown (1909: 65, figs 1-2), Swartz (1929: 52, pl. 8/13-14). A Pragian record (Yu \& Liao 1978: 250, pl. 1/8a-b) from Yunnan (China) is a misidentified pleonophorous taxon.

Paterophyllum explanans Počta, 1902 (214, pl. 114/8-9), Pragian (Dvorce-Prokop Limestone), Barrandian area, Bohemia (Czech Republic), genolectotype of Paterophyllum Počta, 1902 (designated by Grabau 1928: 18). Without thorough revision of the type series, an interpretation and orientation of the septal apparatus appears impossible.

Paterophyllum perlatum Počta, 1902 (212, pl.114/10-12), probably Eifelian (?Choteč Limestone), the Barrandian area, Bohemia (Czech Republic).

Zaphrentoides (Rhipidophyllum) ampliseptatus Weissermel, 1941 (202, pl. 6/9), Pragian (Tentaculitid Nodular Limestone), Thuringia; initial revision in Weyer (1984: 11, fig. 1/2, fot. $2 / 2$ ).

Palaeocyathus n. sp. (Weyer 1984: 11, fig. 1/1a-b), Pragian (Tentaculitid Nodular Limestone), of Thuringia (Germany) and Pragian (Dvorce-Prokop Limestone), Barrandian area in Bohemia (Czech Republic). An identity with one of the unrevised Paterophyllum species of Počta (1902) might be possible.

Enterolasma ibericum Kullmann, 1965 (145, fig. 20a-k, pl. 7/ 2-6), Early Emsian (Zlichovian, Mimosphinctes cantabricus Zone), Cantabrian Mountains in northern Spain. A rather similar species occurs in the Late Emsian (Nowakia cancellata and Nowakia richteri Zones), Morocco (Dra valley sections).

Orthopaterophyllum kazakstanicum Nikolaeva in Bul'vanker, 1952 (7, 8), Lochkovian (Ainasu Horizon), central Kazakhstan, fully described by Nikolaeva in Bul'vanker et al. (1960: 222, figs 27a-d, 28, pl. 45/5-7, with changed spelling as "kasachstanicum"). The first, but unpublished, description by Nikolaeva (manuscript 1935, of superior quality for those times), and proposing the new genus, was cited by Bul'vanker (1952). In the sense of the International Rules of Zoological Nomenclature, Orthopaterophyllum and its type species $O$. kazakstanicum therefore have authorship "Nikolaeva in Bul'vanker 1952". Complete published description of the genotype did not occur until 1960, but the generic diagnosis and the remarks differentiating O. kazakstanicum from her new species Orthopaterophyllum conicum, used by Bul'vanker (1952), can be accepted also as a sufficient, though extremely short, characterization of the type species (Flügel 1970: 189).

Orthopaterophyllum cornuforme Nikolaeva in Bul'vanker et al., 1960 (224, fig. 29a-d, pl. 45/1-4), Lochkovian (Ainasu Horizon), central Kazakhstan.

Orthopaterophyllum tschernyschewi Spasskiy, 1960 (23, pl. 26/ 6-9), Late Emsian, Russian Rudny Altay. The original stratigraphic age "Lower Eifelian" has changed since the general worldwide redefinitions around the Emsian-Eifelian boundary; Dubatolov \& Kozlov (1980: 34) indicated Late Emsian for the Kryukovskiy Horizon, the Leninogorsk region, and this level was placed into the Early and Late Emsian also by Talent et al. (2001: 79, fig. 6). Further Asiatic records are contributed by Spasskiy (1971: 81, pl. 28/1, Emsian, the Dzhungarian Alatau and of the Pribalkhash in Kazakhstan).
Enterolasma dutroi Oliver, 1989 (10, pl.7/1-8), Emsian/Eifelian boundary level, USA.

Orthopaterophyllum junggarense Cai in Zheng \& Cai, 1983 (134, pl. 32/7a-b), Early Devonian, Xinjiang (China).

Orthopaterophyllum junggarense qinheense Cai in Zheng \& Cai, 1983 (135, pl. 32/3), Early Devonian, Xinjiang (China).

Enterolasma sinense Cai in Zheng \& Cai, 1983 (134, pl. 31/ 11a-b), Early Devonian, Xinjiang (China).

Questionable species, originally or subsequently assigned to Palaeocyathus (or its synonyms accepted here), are the following taxa; all of them need modern morphological revision. Some of these species erected a century ago have never been studied by adequate thin sectioning (McLean 1976).

Cyathophyllum daytonense Foerste, 1890 (339, pl. 9/9-11, proposed as a variety of Cyathophyllum celator), Llandoverian (upper Medinan, Brassfield Limestone), Ohio (USA); refigured Foerste (1931: pl. 17/12, as Enterolasma? daytonense) - not yet revised by sectioning.

Cyathophyllum facetum Foerste, 1890 (341, pl. 9/8), Llandoverian (upper Medinan, Brassfield Limestone), Ohio (USA); refigured Foerste (1931: pl. 17/10, as Enterolasma facetum) not yet revised by sectioning.

Streptelasma geometricum Foerste, 1890 [345, pl. 9/7,12,13, proposed as a variety of Palaeocyathus caliculus (Hall, 1852)], Llandoverian (upper Medinan, Brassfield Limestone), Ohio (USA); refigured Foerste (1931: pl. 17/11, as Zaphrentis? geometricum) - not yet revised by sectioning.

Paterophyllum consimile Počta, 1902 (210, pl. 113/15), Ludlovian (Kopanina Formation), Barrandian area, Bohemia (Czech Republic).

Paterophyllum humile Počta, 1902 (211, pl. 113/19), probably Emsian (Suchomasty Limestone) from the Barrandian area, Bohemia (Czech Republic). For stratigraphical position see Oliver \& Galle (1971: 95).

Orthopaterophyllum sharburense Cai in Zheng \& Cai, 1983 (134, pl. 32/2), Emsian, Xinjiang (China); also in Liao \& Cai (1987: 700, pl. 4/4).

The following taxa, sometimes included in Palaeocyathus or its synonyms, are definitely rejected from that genus.

Paterophyllum praematurum Smith, 1930 (305, fig. 5), Llandoverian, Shropshire (England), reassigned to Orthopaterophyllum Nikolaeva in Bul'vanker, 1952 by Nikolaeva (1960: 222). At present, only the holotype specimen exists and it can not be classified definitively on the basis of the 5 cross sections illustrated by its author. However, the cardinal fossula with a well shortened cardinal septum perhaps indicates a closer relationship to Rhegmaphyllum Wedekind, 1927.

Regmaphyllum [sic] tabulatum Soshkina, 1937 (85, pl. 15/7-8), Emsian, northern East-Ural Mountains, refigured by Ivanovskiy \& Shurygina (1975: 36, pl. 14/3a-b) and transferred to Enterolasma. The species became the genotype of Zelophyllia Soshkina, 1952 (74, figs 69, 103a-b), which later was synonymized with Chlamydophyllum Počta, 1902 (Soshkina et al. 1962: 309; Spasskiy 1977: 92, pl. 17/9; conditionally also Hill 1981: F175). Both Besprozvannykh (1964: 58) and Oliver \& Galle (1971: 77) did not accept this identity. Several features (minor septa mostly contraclin to contratingent, especially at the antiseptal triade, no axial synapticulae in longitudinal section) preclude any relationship with Palaeocyathus, and Zelophyllia can not be regarded as a synonym of Enterolasma (Ivanovskiy 1976: 188).

Paterophyllum apertum Soshkina, 1955 (121, pls 7/1, 12/1a-b), late Llandoverian, Lower Podkamennaya Tunguska River (Siberia). Generic assignment was changed by Ivanovskiy (1963: 41, pl. 8/2) to his new genus Porfirieviella, and by 

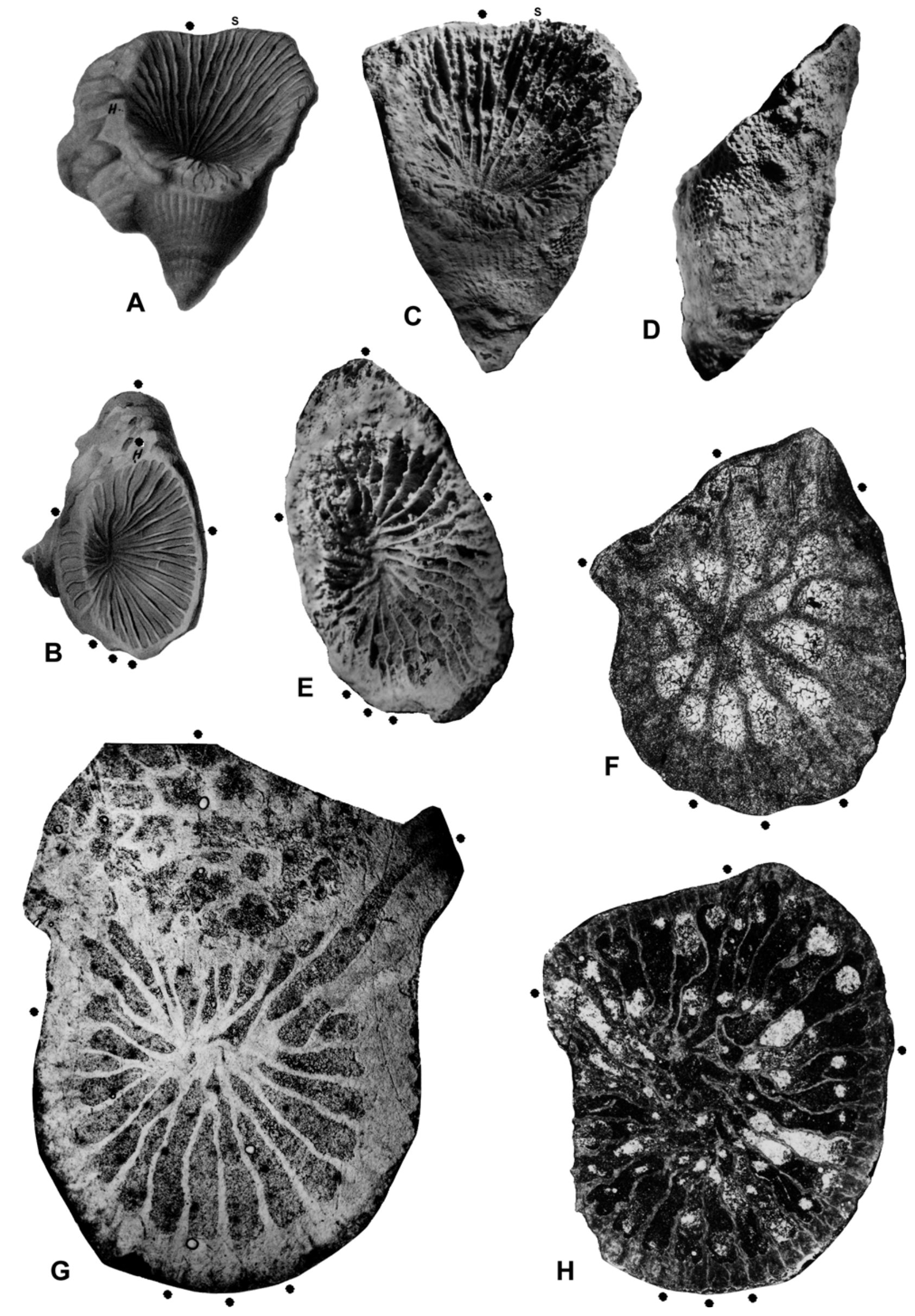
Latypov (1978: 74, pls 22/2, 23/1) to Dinophyllum Lindström, 1882 (probably accepting the synonymy of Porfirieviella with Dinophyllum, as proposed by Ivanovskiy 1970: 121, and 1976: 134). The presence of a well developed cardinal fossula precludes any relationship with Palaeocyathus.

Enterolasma? sp. (Gorskiy 1935: 39, fig. 19, pl. 7/7), Late Famennian ("Etroeungtian"), southern Novaya Zemlya island (Russia). This unusual young record was much doubted by its author himself.

\section{Palaeocyathus posthumus (Weissermel, 1925)} Figs $1 \mathrm{~A}-\mathrm{H}, 2 \mathrm{~A}-\mathrm{H}$

\begin{tabular}{|c|c|c|}
\hline & 1925 & $\begin{array}{l}\text { Triadophyllum posthumum Weissermel: } 25 \text {, pl. } 2 \text { : } \\
\text { figs } 7-8 \text {. }\end{array}$ \\
\hline & 1928 & $\begin{array}{l}\text { Triadophyllum posthumum. - Schmidt: 116, } \\
\text { fig. } 213 \text { (copy of Weissermel 1925) }\end{array}$ \\
\hline & 1956 & $\begin{array}{l}\text { Triadophyllum posthumum - Wells: F378, } \\
\text { fig. } 267 / 1 \mathrm{a} \text {, b (copy of Weissermel 1925) }\end{array}$ \\
\hline non & 1966 & $\begin{array}{l}\text { Triadophyllum cf. posthumum. - Kolosváry: } \\
\text { 126, pl. 2/7-8. }\end{array}$ \\
\hline
\end{tabular}

Holoty pe. By monotypy, specimen no. BGR-Berlin-X10137; being in 1957 (after return from Leningrad) the corallum figured by Weissermel (1925), later in 1977 sectioned by me without destroying the free calice, now consisting of 7 cross sections (6 peels, 1 thin section) and 3 remaining pieces.

Type horizon and locality. Silurian (Llandoverian, Wenlockian or Ludlovian, without more precise age determination), of Baltoscandian origin, found in a Pleistocene (glacial ice drift) erratic boulder in the quarries of Rüdersdorf, southeast of Berlin (situated there in the moraine lying above the exploited marine Middle Triassic rocks of the Lower Muschelkalk = Rüdersdorf Formation). A more detailed age assignment might perhaps be possible in the future, if the species once is found in regions of its probable real origin, Gotland or Estonia.

Diagnosis. Major septa thin and slender, bearing spines on their sides; minor septa tiny. Interseptal spaces wide both in youth and maturity. Septal index high (48 and 60 at diameters of $7 \mathrm{~mm}$ and $10-12 \mathrm{~mm})$.

Description. The external configuration (Fig. 1AE) is well described and illustrated in Weissermel (1925). The conical, slightly cornute corallum (one lateral septum approximately at convex side) has a length of at least $26 \mathrm{~mm}$ and a distal diameter of nearly $17 \times 20 \mathrm{~mm}$. The laterally situated cardinal side bears a large and elongated talon (really seen only in the cross sections); the coral used a small Tabulata colony (Favositidae) as a hardground. The great calicular depth - estimated by Weissermel as $54 \%$ of corallum length - amounts to even $77 \%$ according to direct observation after sectioning. A normal rugosan archaeothecal structure with strong longitudinal septal furrows (already suspected by Weissermel) is now proved by the cross sections, too. Preservation in calcite appears excellent in the rugose and tabulate corals and in its epizoan Bryozoa. There are no signs of the usual Scleractinian recrystallisation of primary aragonite.

The mostly free calice (etched by Weissermel with potassium hydrate treatment) allows the identification of all six protosepta and of the four growth centers where new septa arise.

A misinterpretation by Weissermel (1925: 27; see Fig. 1A, C - wrong lateral septum marked "S" = German "Seitenseptum") is rather curious and should be explained by the judgment of Schindewolf (1952: 172, below) as in a similar case with Heritsch (1941). There does not exist any deviation from the more or less bilaterally symmetrical standard insertion plan in Rugosa (Hill 1981: F20, fig. 11/3-4, non fig. 11/1-2). As distal septal margins show some corrosion, their septal microstructure remains somewhat doubtful, but seems to be trabecular (perhaps spinose margins).

At maturity, the septal apparatus consists of 66 septa, with 37 being major ones in a predominantly radial position. In middle calicular parts, their slightly enlarged peripheral bases have a denser ornamentation which mostly weakens towards the calicular floor after some stereoplasmatic thickening. Middle and central parts of these major septa remain thin and slender, with thickening only at their axial ends when reaching the center and loosely connecting with neighbouring ones. The flanks of major septa are distinctly ornamented by spines and flanges, which should be arranged in lines parallel to the distal septal margin. At two places, metriophylloid carinae seem to be developed (Fig. 2F left, Fig. $2 \mathrm{G}$ right cardinal quadrant), but their precise course, angular or parallel to the distal margin, remains undetermined.

Nearly all major septa (including the cardinal and counter) are of equal length. The only exceptions sometimes occur at the four growth poles just

Fig. 1. Palaeocyathus posthumus (Weissermel, 1925), Holotype, Pleistocene erratic boulder from the Silurian of Baltoscandia, Rüdersdorf quarry (still exploiting today limestones of the Rüdersdorf Formation = former Lower Muschelkalk Beds) southeast of Berlin, coll. Oskar Raab 1888, collections of the Bundesanstalt für Geologie und Rohstoffe, Berlin Department (former Prussian Geological Survey), no. BGR-Berlin-X10137. A, B - Side and calicular view of corallum, $\times 2$ (retouched photographs, copied from Weissermel 1925: pl.2/7-8); letters H and S of Weissermel indicate the cardinal septum and one misidentified lateral septum (the real lateral septum is marked by a new black dot); $\mathbf{C}, \mathbf{D}, \mathbf{E}-$ actual photographs of the corallum (before sectioning), $\times 2.5$ (C, D - side views, with Bryozoa epizoans), and $\times 3$ (E - calice, with marked six protosepta); F, G, $\mathbf{H}$ - cross sections in calicular view, with marked six protosepta, $\times 20$ (F - no. 7, subtabular), $\times 10(\mathrm{G}-$ no. 3 , calicular, with talon covering a favositid Tabulata colony), and $\times 6(\mathrm{H}-$ no. 1 , calicular $)$; drawings see Figs $2 \mathrm{~A}, \mathrm{E}, \mathrm{G}$. 

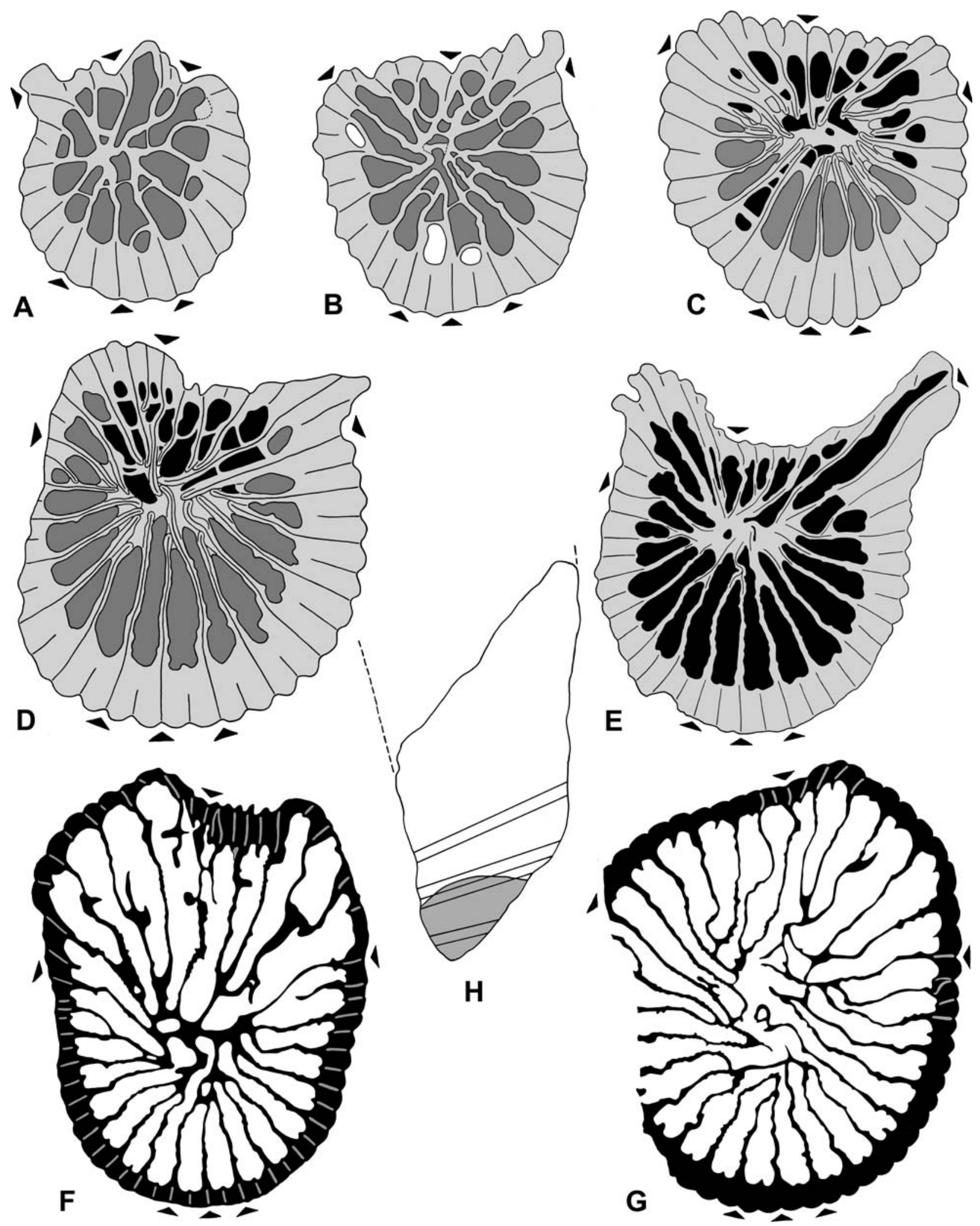

Fig. 2. Palaeocyathus posthumus (Weissermel, 1925), Holotype, Pleistocene erratic boulder from the Silurian of Baltoscandia, Rüdersdorf quarry (still exploiting today limestones of the Rüdersdorf Formation = former Lower Muschelkalk Beds) southeast of Berlin, coll. Oskar Raab 1888, collections of the Bundesanstalt für Geologie und Rohstoffe, Berlin Department (former Prussian Geological Survey), no. BGR-Berlin-X10137. A-G - Serial cross sections (no. 7-1, all peels excepting thin section of D), $\times 15(\mathrm{~A}), \times 12(\mathrm{~B}), \times 10(\mathrm{C}, \mathrm{D}), \times 8(\mathrm{E})$, and $\times 6(\mathrm{~F}, \mathrm{G})$; subtabular $(\mathrm{A}, \mathrm{B})$, at calicular base $(\mathrm{C}, \mathrm{D})$, and completely calicular $(\mathrm{E}-\mathrm{G})$; subtabular lumina grey in $\mathrm{A}, \mathrm{B}$, and black in $\mathrm{C}, \mathrm{D}$; calicular lumina grey in $\mathrm{C}, \mathrm{D}$; black in $\mathrm{E}$; and white in $\mathrm{F}$, $\mathrm{G}$; distance above base of corallum $2.3 \mathrm{~mm}(\mathrm{~A}), 2.9 \mathrm{~mm}(\mathrm{~B}), 5.3 \mathrm{~mm}(\mathrm{C}), 6.0 \mathrm{~mm}(\mathrm{D}), 6.8 \mathrm{~mm}(\mathrm{E}), 9.0 \mathrm{~mm}(\mathrm{~F})$, and $9.7 \mathrm{~mm}$ ( $\mathrm{G}$, situated $16.3 \mathrm{~mm}$ below upper calicular rim); photographs see Fig. 1. H - Corallum in side view, with indicated positions of the 7 available cross sections (reconstructed subtabular part grey). 
after insertion, when the newly created major septa still remain shorter - thus indicating a pinnate arrangement (Fig. 2A, E, F), which soon changes to the general radial position. Sometimes this transition may pass rather quickly, if the last major septum of a quadrant is axially connected with the cardinal septum (Fig. 2D, G). The remarkable talon has caused drastic deformations in septal symmetry of the cardinal quadrants.

The typical axial synapticulae of the genus Palaeocyathus, with their continuously alternating connections to the two neighbouring major septa, could be deduced only from the series of cross sections. Clearer view of the synapticulae would have been seen in a median longitudinal section, but that was not possible from the unique holotype specimen without destroying it too much. The structure is best seen in the counter quadrants of quite narrowly positioned sections (Fig. 2D-G). There axially united pairs of major septa change their partner, and some isolated septal lobes cross the center.

Short, free minor septa seem to "appear" in later stages (Fig. 2E-G), thus deceiving a cyclic mode of insertion which never occurs in Rugosa. In reality, the minor septa start (according to the law of Ludwig/Kunth) already in early youth, are active only in the upper calicular phases, and become reduced by stereoplasmatic internal thickening of the archaeotheca in lower calicular levels. Then they are hidden within the wall after that primary calyx ontogenesis, but are still clearly discernable by the well developed external septal furrows and by growth line structures inside the wall. The two counter minor septa do not differ from the other ones by greater length; only their slightly earlier "reappearance" (Fig. 2D) may be noted.

During ontogenesis, interseptal lumina are quite large; the amount of early stereoplasmatic skeletal thickening is rather low (with proportional exception of the wall). Therefore, the loose central connection of major septa by axial synapticulae starts very early (Fig. 2B). Spines and flanges of major septa flanks are distinctly weaker in the early growth stages. In part, this seems to be real, but on the other hand it is also due to the secondary postcalyx ontogeny shown in subtabular sections (after little stereoplasmatic skeletal thickening partially obscuring flank ornamentation during the final phases of the primary calyx ontogenesis). Ephemeral appearances of an apparent more dense axial structure (Fig. 2C-E) are mainly caused by flat central parts of tabulae just met with in such sections.

The specimen offers the following septal formulae during its ontogenesis $(n=$ number of major septa, $\mathrm{N}=$ number of all septa, $\mathrm{D}=$ diameter). The final calicular stage (Fig. 1E) had to be reconstructed slightly: its corroded left counter quadrant offers only 9 major septa, but is situated much deeper than the right one.

$\begin{array}{llllllll} & \frac{2 \mid 2}{4 \mid 5} & \frac{2 \mid 2}{5 \mid 5} & \frac{3 \mid 4}{6 \mid 6} & \frac{4 \mid 4}{7 \mid 7} & \frac{5 \mid 4}{7 \mid 8} & \frac{6 \mid 6}{9 \mid 9} & \frac{6 \mid 6}{10 \mid 11} \\ \mathrm{n} & 17 & 18 & 23 & 26 & 28 & 34 & 37 \\ \mathrm{~N} & 28 & 31 & 38 & 44 & 48 & 60 & 66 \\ \mathrm{D}(\mathrm{mm}) & 1.9 & 2.4 & 3.6 & 4.2 & 6.8 & 9.6 \times 12.6 & 17 \times 20 \\ \text { Fig. } & 2 \mathrm{~A} & 2 \mathrm{~B} & 2 \mathrm{C} & 2 \mathrm{D} & 2 \mathrm{E} & 2 \mathrm{~F}-\mathrm{G} & 1 \mathrm{E}\end{array}$

A diaphragmatophorous structure in the basal parts (Fig. 2A-D) is indicated by tabular intersections, which always run concave towards the periphery. That allows the reconstruction of simple uniform domed tabulae (obviously without tabellae and true cardinal fossula). There are no dissepiments.

Comparisons. The unique holotype belongs to a provisional species group around Palaeocyathus

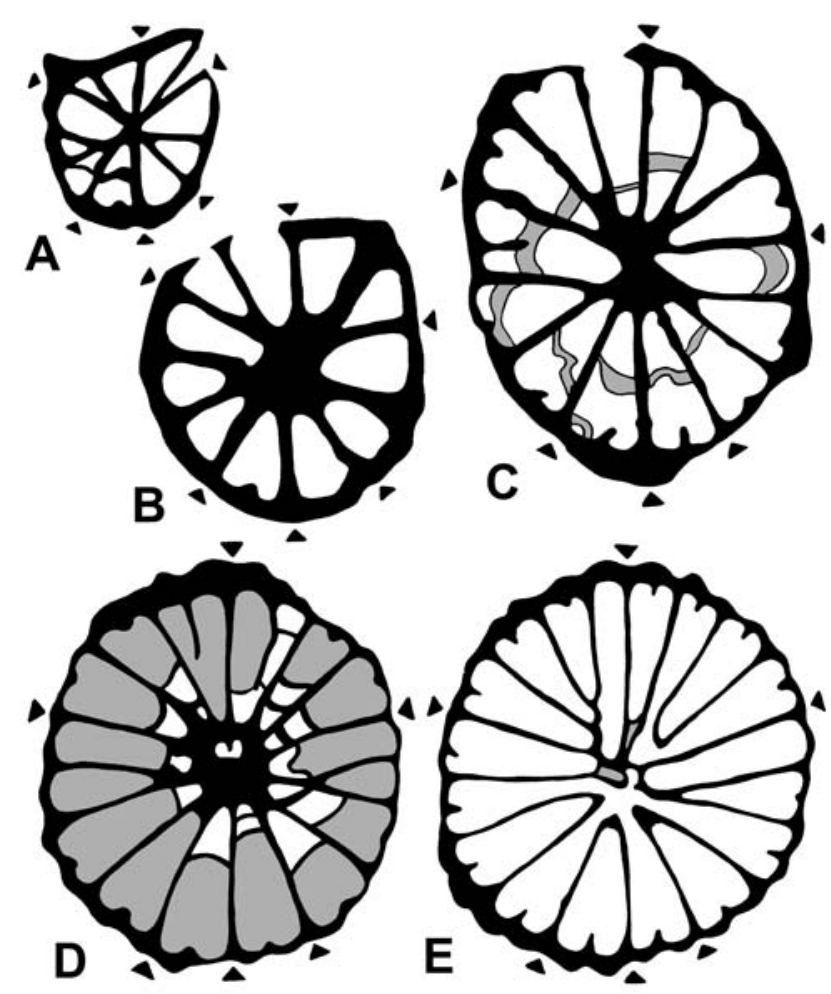

Fig. 3. Palaeocyathus sp. cf. bohemicus (Počta, 1902), unknown horizon (probably Ludlovian, Kopanina Formation), unknown locality in the Barrandian area, Bohemia (Czech Republic), coll. J. Barrande - P. Počta (from National Museum Prague), donated as duplicate material by Jan Koliha (1890-1939) ca. 1925 to O. H. Schindewolf, Prussian Geological Survey Berlin, now in Museum of Natural History, Humboldt University, Berlin, no. MB.K.2309. Specimen prepared by Schindewolf, indicating: external habit similar to Petraia levis Počta, 1902 (pl. 68/10) and Alleynia curta Počta, 1902 (pl. 68/25); $=6$ cross sections (in 2 thin sections) and 2 remaining pieces. The straight, slender conical corallum (with a distal diameter of $10 \times 11 \mathrm{~mm}$ ) has an archaeotheca with weak growth rugae and strong longitudinal septal furrows, and a calicular depth of at least $6 \mathrm{~mm}$ showing only very tiny septal protuberances. A-E - Serial cross sections (A-C - subtabular; D, E - at calicular base), with indisputably identified protosepta, $\times 18(\mathrm{~A}, \mathrm{~B}), \times 15(\mathrm{C}-$ thickened tabular intersections grey), $\times 12 \quad(\mathrm{D}-$ subtabular spaces white), and $\times 10$ ( $\mathrm{E}-$ subtabulat spaces grey). See photos of Fig. 4. 

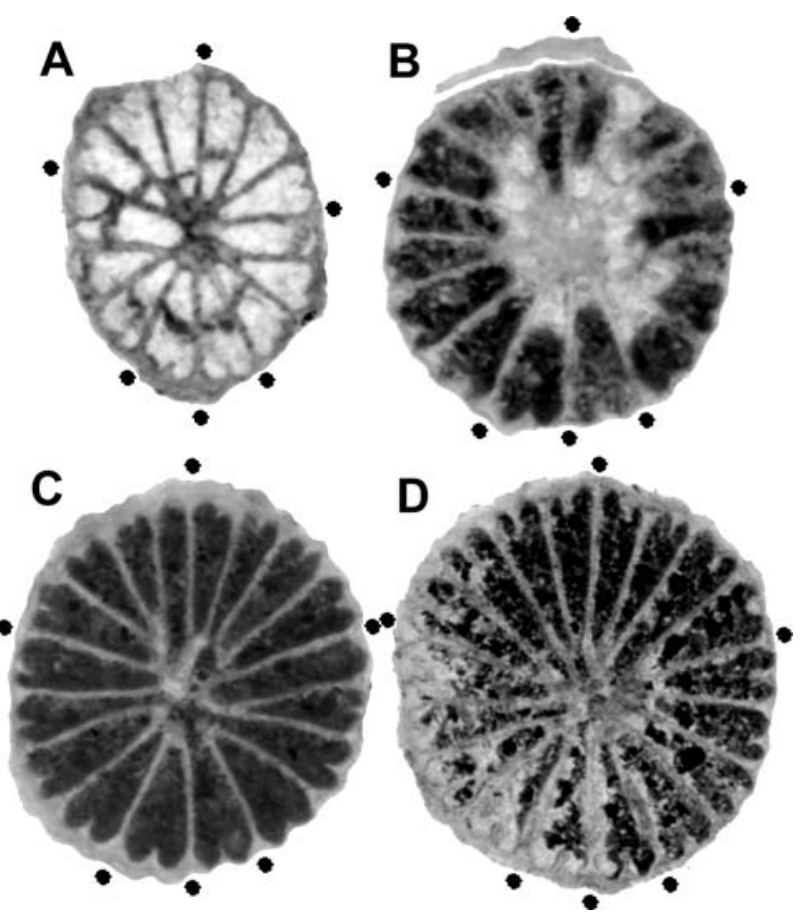

Fig. 4. Palaeocyathus sp. cf. bohemcius (Počta, 1902), same specimen as Fig. 3 (no. MB.K.2309.). A-D - Serial cross sections (A - subtabular; B, C - at calicular base; D - calicular), $\times 12(\mathrm{~A}, \mathrm{~B}), \times 10(\mathrm{C})$, and $\times 8(\mathrm{D})$. See drawings of Fig. 3 .

australis Foerste, 1888, proposed by McLean (1976) for taxa with thin major septa. Its somewhat better known Silurian representatives are the possibly nearest type species Palaeocyathus australis (differing by a smaller septal index and slightly longer minor septa with spiny flanks - see McLean 1976), and the more different Palaeocyathus caliculus (Hall, 1852), with smooth major septa without lateral spines or flanges (Brown 1909). A further well redescribed Silurian species is Palaeocyathus waynensis (Safford, 1869), distinguished by its much

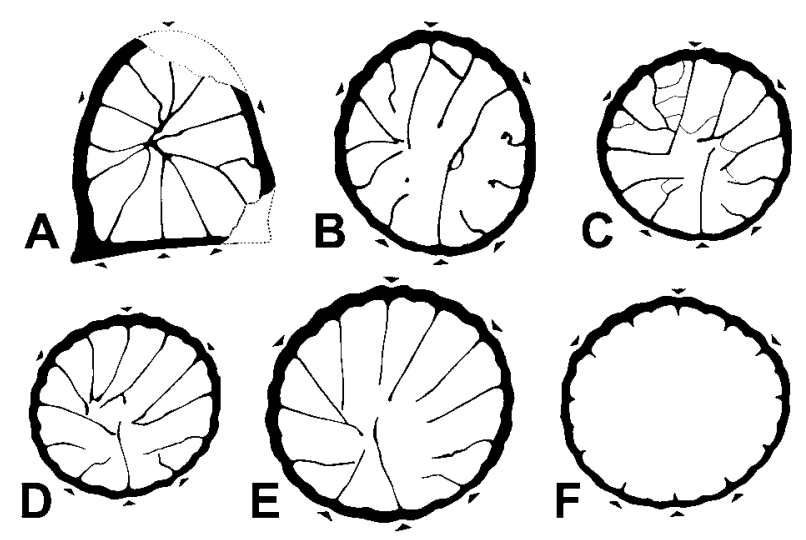

Fig. 5. Palaeocyathus sp. aff. radiatus (Münster, 1839), Ludlovian, Elbersreuth „Orthoceratite“ Limestone, Schübelberg near Elbersreuth, Upper Franconia (Germany), coll. G. Münster ca. 1835 (paralectotype of Petraia semistriata Münster, 1839), no. MB.K.128.; copied from Weyer (1980). A-F subtabular $(\mathrm{A}, \mathrm{B})$ and calicular $(\mathrm{C}-\mathrm{F})$ cross sections, $\times 8$ $(\mathrm{A}), \times 7(\mathrm{~B}), \times 6(\mathrm{C}, \mathrm{E})$, and $\times 5(\mathrm{D}, \mathrm{F})$.

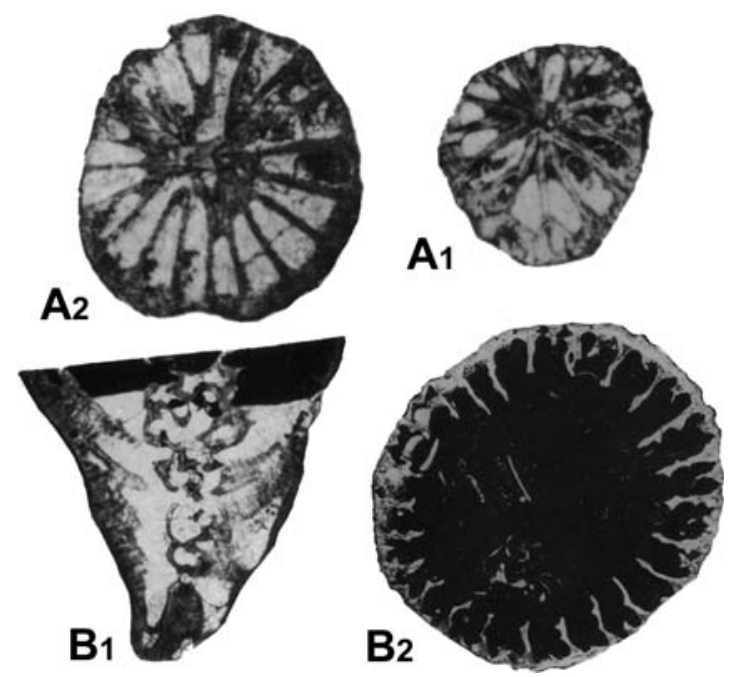

Fig. 6. Palaeocyathus conicus (Bul'vanker, 1952), early Wenlockian (Sheinwoodian), Kitaigorod Horizon, left bank of Studenitsa river above its mouth into the Dnestr river, Podolia (Ukraine), coll. O. N. Nikiforova 1934 (VSEGEI St. Peterburg); copied from Bul'vanker (1952). A1-2 - Specimen 1952: pl. 6, figs 6b,c; juvenile cross sections, $\times 6$; $\mathbf{B}_{\mathbf{1 - 2}}-$ specimen 1952: pl. 5, fig. 2, pl. 6, fig. 5; mature longitudinal and calicular cross section, $\times 3$ (cross sections without protoseptal orientation).

longer minor septa, the smaller septal index, and the spindle-like thickening of major septa at their mid-length (Sutherland 1965).

At present, there is no other species comparable to Palaeocyathus posthumus with its outstanding features of an unusual high septal index and rather thin major septa having spinous sides; but it has to be remembered that several taxa of the genus are only very poorly known and in strong need of modern revisions. My collections of ahermatypic Rugosa from the Silurian of Gotland and Estonia did not yield the genus. Among Lochkovian species, Palaeocyathus kazakstanicus (Nikolaeva in Bul'vanker, 1952) is the closest, but also never reaches a similar high septal number (see the illustrations of Nikolaeva in Bul'vanker et. al. 1960).

Discussion. In contrast to most Silurian corals from Pleistocene erratic boulders of Baltoscandian origin, which represent hermatypic shallow water groups, Palaeocyathus is an ahermatypic genus (Sutherland 1965: recorded only from locality P6 of the Ludlovian Henryhouse Formation together with other cold water taxa; Oliver \& Sorauf 1983: 46, fig. 3 - Enterolasma facies within the Lochkovian Helderbergian; my rich Early Devonian material from Germany, the Czech Republic, Spain and Morocco). That facies type seems to occur extremely rarely among mid-European Silurian erratics, e.g. the facies with Sutherlandinia erratica Weyer, 1978. However, this may simply reflect a general lack of studies of such small and neglected Rugosa. 
This is also true for the famous Silurian outcrops of Gotland and Estonia, where hitherto no record of Palaeocyathus exists. When showing my drawings of Triadophyllum posthumum to Björn Neuman (1935-2006) in 1997, he confessed that he did not know such a coral from Gotland. Of course, several clearly ahermatypic, but poorly studied communities, also containing undescribed taxa, do occur: e.g. Early Llandoverian (Rhuddanian) of Hiumaa Island, Estonia (local facies of Hilliste Formation, Juuru Stage) - genus Densiphyllum Dybowski, 1873; early Wenlockian (Sheinwoodian) of Saarema Island, Estonia (Paramaja facies of Jaani Horizon); early Wenlockian (Sheinwoodian-Homerian) of Gotland (Slite Beds) - laccophyllid fauna (Weyer 1978, Neuman 1988).

The nearest European Silurian record of a Palaeocyathus is from Podolia (Ukraine) - Kitaigorod Horizon (early Wenlockian, Sheinwoodian) (Bul'vanker 1952; Sytova 1975). This Palaeocyathus conicus (Bul'vanker, 1952) (Fig. 6) differs from Palaeocyathus posthumus in the much lower number of septa (48 instead of 60) at comparable diameter. Next Silurian occurrences belong to originally distant, Gondwana-derived terranes. The new generic combination for Palaeocyathus bohemicus (Počta, 1902) from the Ludlovian Kopanina Formation of the Barrandian (Bohemia, Czech Republic) is based on the clear drawings of its author and on an additional specimen (Figs 3-4). The main difference from Palaeocyathus posthumus is the smooth configuration of major septal flanks, not bearing spines or flanges. The same is true also for Palaeocyathus radiatus (Münster, 1839) and Palaeocyathus sp. of Weyer (1980: 34, fig. 6) from the Ludlovian "Elbersreuth Orthoceratite Limestone" of Upper Franconia (Saxothuringia, Germany) (Fig. 5), with extremely thin septa.

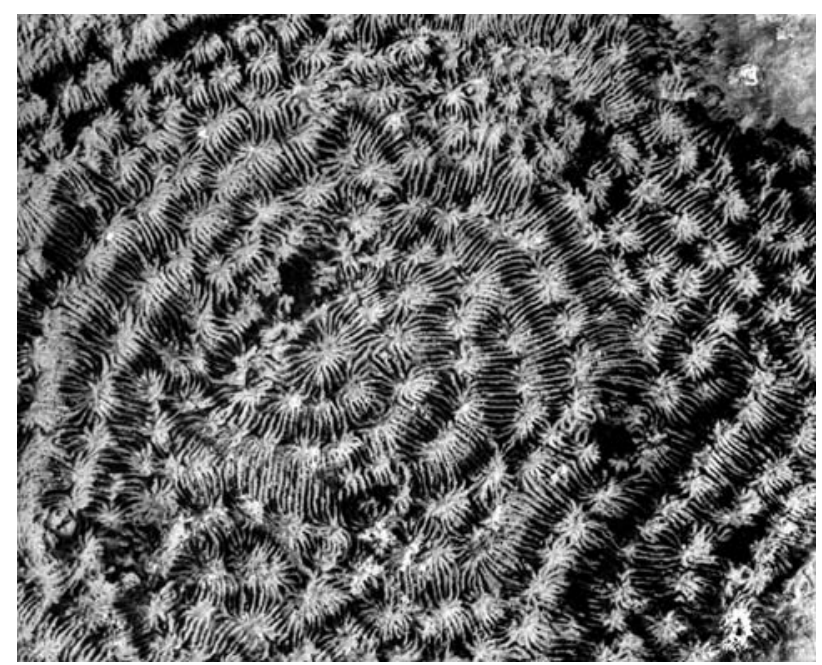

Fig. 7. Pamiroseris silesiaca (Beyrich, 1852), "Schaumkalk" (Rüdersdorf Formation, Anisian) of Rüdersdorf quarry, SE of Berlin, coll. O. Raab 1902 (BGR Berlin). Cast preservation (typical for German Lower Muschelkalk localities), $\times 1.5$.

\section{Acknowledgements}

Wolfgang Lindert, Berlin (Bundesanstalt für Geologie und Rohstoffe, BGR-Berlin) always made available the palaeontological collections of that institution, including the unique holotype of Triadophyllum posthumum. Walter Neben (1901-1979), well known Berlin amateur collector of (mainly Palaeozoic) fossils from Pleistocene erratic boulders, had told me some historical stories of 1925 and 1942 (insider knowledge about Waldemar Weissermel, Edmund Picard, and Otto Heinrich Schindewolf, concerning the wrong Triassic age of Triadophyllum posthumum) in 1965, when I was just starting with coral studies. Extensive collections of Silurian comparative coral material could be procured during excursions to Estonia in 1996, with the kind help of Dimitri Kaljo, Tallinn, Estonian Academy of Sciences, and to Gotland in 1997, under guidance of Björn Neuman (1935-2006), then Bergen University, Institute of Geological Sciences. Special discussions on the Triadophyllum problem were held in 1977 with Tamara Gennad'evna Il'ina (1924-2003), then Moscow (Palaeontological Institution, Academy of Sciences) during her Berlin visit. Reviews by Ross A. McLean (Calgary), Ewa Roniewicz (Warszawa), and Stefan Schröder (Köln) contributed to the both scientific and linguistic improvement of a first draft. I am deeply indebted to all of them for their kind help in preparing this taxonomic revision.

\section{References}

Alloiteau, J. 1952. Madréporaires post-paléozoiques. - In Piveteau, J. (ed.). Traité de Paléontologie. Tome premier. Introduction, Généralités, Protistes, Spongiaires, Coelentérés, Bryozoaires: 539-684, Masson, Paris.

Amsden, T. W. 1949. Stratigraphy and Paleontology of the Brownsport Formation (Silurian) of Western Tennessee. Bulletin, Peabody Museum of Natural History Yale University 5: 1-138.

Bachmann, G. H., Beutler, G., Hagdorn, H. \& Hauschke, N. 1999. Stratigraphie der Germanischen Trias. - In Hauschke, N. \& Wilde, V. (eds). Trias. Eine ganz andere Welt. Mitteleuropa im frühen Erdmittelalter: 81-104, Verlag Dr. Friedrich Pfeil, München.

Ball, J. R. \& Grove, B. H. 1940. New Species of Corals from the Bainbridge Limestone of Southeastern Missouri. The American Midland Naturalist 24 (2): 382-404.

Balogh, K. 1964. A Bükkhegység földtani kópzödmenyei. [Die geologischen Bildungen des Bükk-Gebirges]. - Évkönyve, Magyar Állami Földtani Intézet [Annales Instituti Geologici Publici Hungarici] 48 (2): 241-719.

Bendukidse, N. S. \& Chikovani, A. A. 1962. Podklass Hexacoralla. Shestiluchevye korally. - In Orlov, Yu. A. (ed.). Osnovy Paleontologii, [vol. 2], gubki, arkheotsiaty, kishechnopolostnye, chervy [Porifera, Archaeocyatha, Coelenterata, Vermes]: 357-422, Moskva (Izdatel'stvo Akademii Nauk SSSR).

Besprozvannykh, N. I. 1964. Korally Rugosa srednedevonskikh otlozheniy Kolyvan'-Tomskoy skladchatoy zony (Ob'-Zaysanskaya skladchataya oblast'). [Rugosa corals from the Middle Devonian of the Kolyvan-Tomsk folding zone (Ob-Zaisan folding region)]. - In Sokolov, B. S. (ed.). Siluriyskie i devonskie korally Aziatskoy chasti SSSR. [Silurian and Devonian corals from the Asiatic part of USSR]: 50-79, Institut Geologii i Geofiziki, Sibirskoe Otdelenie, Akademiya Nauk SSSR, Moskva (Izdatel'stvo Nauka).

Beyrich, E. 1852. Über das Vorkommen von Korallen und Schwämmen im Muschelkalk ausserhalb der Alpen. Zeitschrift der deutschen geologischen Gesellschaft 4 (2): 216-218.

Brown, T. C. 1909. Studies on the Morphology and Development of Certain Rugose Corals. - Annals of the New York Academy of Sciences 19 (1, 3): 45-97. 
Bul'vanker, E. Z. 1952. Korally rugoza silura Podolii. [Rugose corals from the Silurian of Podolia]. - Trudy Vsesoyuznogo Nauchno-Issledovatel'skogo Geologicheskogo Instituta (VSEGEI): 1-33, Gosgeolizdat, Moskva.

Bul'vanker, E. Z., Vasilyuk, N. P., Zheltonogova, V. A., Zhizhina, M. S., Nikolaeva, T. V., Spasskiy, N. Y. \& Shchukina, V. Y. 1960. Novye predstaviteli chetyrekhluchevykh korallov SSSR. [New representatives of Tetracorals from the USSR]. - In Markovskiy, B. P. (ed.). Novye vidy drevnikh rasteniy i bespozvonochnykh SSSR, [vypusk 1, chast' 1]. [New species of fossil plants and invertebrates of the USSR; 1(1)]. - Vsesoyuznyy Nauchno-Issledovatel'skiy Geologicheskiy Institut (VSEGEI): 220-254; 510-545, Gosgeoltekhizdat, Moskva.

Cuif, J.-P. 1975. Caractères morphologiques, microstructuraux et systématiques des Pachythecalidae, nouvelle famille de Madréporaires triasiques. - Geobios 8 (3): 157-180.

- 1977. Arguments pour une relation phylétique entre les Madréporaires paléozoiques et ceux du Trias. Implications systématique de l'analyse microstructurale des Madréporaires triasiques. - Mémoires de la Société Géologique de France, nouvelle série 56 (no. 129): 1-54.

Dienst, P. 1933. Vorweisung eines montierten Skeletts von Nothosaurus sp. aus dem Mittleren Muschelkalk von Rüdersdorf. - Jahrbuch der Preußischen Geologischen Landesanstalt 1932, 53 (Sitzungsberichte): 1-3.

Dienst, P. \& Gothan, W. 1928. Zusammenstellung der im Geologischen Landesmuseum zu Berlin aufbewahrten Originale. 228 pp., Preußische Geologische Landesanstalt, Berlin.

Dockter, J., Puff, P., Seidel, G. \& Kozur, H. 1980. Zur Triasgliederung und Symbolgebung in der DDR. - Zeitschrift für Geologische Wissenschaften 8 (8): 951-963.

Dubatolov, V. N. \& Kozlov, M. S. 1980. Opisanie nizhne-i srednedevonskikh otlozheniy. [Description of Lower and Middle Devonian deposits]. - In Dubatolov, V. N., Dubatolova, Yu. A., Kozlov, M. S. \& Spasskiy, N. Ya. Biostratigrafiya nizhnego i srednego devona Rudnogo Altaya. [Lower and Middle Devonian biostratigraphy of the Rudny Altai]. - Trudy, Institut Geologii i Geofiziki (Akademiya Nauk SSSR, Sibirskoe Otdelenie) 425: 15-68.

Dybowski, W. 1873-1874. Monographie der Zoantharia sclerodermata rugosa aus der Silurformation Estlands, Nord-Livlands und der Insel Gotland, nebst einer Synopsis aller palaeozoischen Gattungen dieser Abtheilung und einer Synonymik der dazu gehörigen, bereits bekannten Arten. - Archiv für die Naturkunde Liv-, Ehst- und Kurlands, Serie 1, 5 (3, 4): 257-532 [1873: 257-414, 1874: 415-532].

Eck, H. 1863. Vorläufige Notiz über die Auffindung der Lettenkohlenformation in Oberschlesien und über die Stellung des Mikultschützer Kalks (Virgloriakalks) im Muschelkalk. - Zeitschrift der deutschen geologischen Gesellschaft 15 (2): 403-410.

- 1865. Über die Formationen des bunten Sandsteins und des Muschelkalks in Oberschlesien und ihre Versteinerungen I-VIII, 148 pp., R. Friedländer \& Sohn, Berlin.

- 1879. Ueber einige Triasversteinerungen. (Korallen, Encrinen, Asterien, Ammoniten, „Stylorhynchus“). - Zeitschrift der deutschen geologischen Gesellschaft 31 (2): 254-281.

Ezaki, Y. 1997. The Permian coral Numidiaphyllum: new insights into anthozoan phylogeny and Triassic scleractinian origins. - Palaeontology 40 (1): 1-14.

- 1998. Paleozoic Scleractinia: progenitors or extinct experiments? - Paleobiology 24 (2): 227-234.

- 2000. Palaeoecological and phylogenetic implications of a new scleractiniamorph genus from Permian sponge reefs, South China. - Palaeontology 43 (2): 199-217.

Flügel, H. W. 1970. Bibliographie der paläozoischen Anthozoa (Rugosa, Heterocorallia, Tabulata, Heliolitida, Trachypsammiacea): 262 pp. (I, Bibliographie); 323 pp. (II, Index zur Bibliographie), Österreichische Akademie der Wissenschaften, Wien.
- 1976. Numidiaphyllidae - eine neue Familie der Rugosa aus dem Ober-Perm von Süd-Tunis. - Neues Jahrbuch für Geologie und Paläontologie, Monatshefte 1976 (1): $54-64$.

Foerste, A. F. 1888. Notes on Paleozoic Fossils. - Bulletin of the Scientific Laboratories of Denison University 3 (2): 117-137.

- 1890. Notes on Clinton Group fossils, with special reference to collections from Indiana, Tennessee and Georgia. Proceedings of the Boston Society of Natural History, for 1889 24: 263-355.

- 1931. The Silurian Fauna of Kentucky. In Jillson, W. R. (ed.). The Paleontology of Kentucky. - The Kentucky Geological Survey, series 6, 36: 167-213.

Frech, F. 1890. Die Korallenfauna der Trias. I. Die Korallen der juvavischen Triasprovinz (Zlambachschichten, Hallstädter Kalke, Rhaet). - Palaeontographica 37 (1, 2-4): $1-116$.

Gorskiy, I. I. 1935. Nekotorye Coelenterata iz nizhnekamennougol'nykh otlozheniy Novoy Zemli. [Some Coelenterata from the Lower Carboniferous beds of the Nowaya Zemlya]. - Trudy [Vsesoyuznogo] Arkticheskogo Instituta 28 (Geology): 1-128.

Grabau. A. W. 1901. Guide to the Geology and Paleontology of Niagara Falls and Vicinity. - Bulletin of the Buffalo Society of Natural Sciences 7 (1): 1-284.

- 1928. Palaeozoic Corals of China. Part I. Tetraseptata II. Second contribution to our knowledge of the Streptelasmoid Corals of China and Adjacent Territories. - Palaeontologica Sinica, series B 2 (2): 1-175.

Hall, J. 1852. Natural History of New York. Part VI. Palaeontology of New York. Volume II. Containing descriptions of the organic remains of the lower middle divisions of the New York system I-VIII, 362 pp., Albany, New York, (Charles van Benthuysen).

- 1874. Descriptions of Bryozoa and Corals of the Lower Helderberg Group. - Annual Report on the New York State Museum of Natural History, by the Regents of the University of the State of New York 1872 26: 93-116.

- 1879. The Fauna of the Niagara Group, in Central Indiana. - Annual Report of the New York State Museum of Natural History 28: 99-203.

- 1882. Descriptions of the Species of Fossils found in the Niagara Group at Waldron, Indiana. - Annual Report, Indiana Department of Geology and Natural History [for 1881] 11: $217-345$

- 1883. Fossil Corals and Bryozoans of the Lower Helderberg Group and fossil Bryozoans of the Upper Helderberg Group. - Assembly Document 178, Report of the State Geologist, State of New York, for 1882 17: 33 pls., Albany (New York).

Hall, J. \& Simpson, G. B. 1887. Palaeontology [of New York]. VI. Corals and Bryozoa. Containing descriptions and figures of species from the Lower Helderberg, Upper Helderberg and Hamilton groups. - Geological Survey of the State of New York, I-XXVI: 1-298, Albany (Charles van Benthuysen), New York.

Harland, W. B., Smith, A. G. \& Wilcock, B. (eds) 1964. The Phanerozoic time-scale. (A symposium dedicated to Professor Arthur Holmes). - Quarterly Journal of the Geological Society 120s, $1-458$.

Heritsch, F. 1941. Tetrakorallen aus dem Oberkarbon von Chios. - Sitzungsberichte der Akademie der Wissenschaften in Wien, mathematisch-naturwissenschaftliche Klasse, Abteilung I 150 (3-6): 131-146.

Hill, D. 1940. The Silurian Rugosa of the Yass-Browning-District, N.S.W. - The Proceedings of the Linnean Society of New South Wales 65 (3-4): 388-420.

- 1956. Rugosa, Heterocorallia. - In Moore, R. C. (ed.). Treatise on Invertebrate Paleontology, Part F, Coelenterata: I-XX, 1-498 (F233-327), New York (Geological Society of America), Lawrence/Kansas (University of Kansas Press). 
- 1981. Rugosa and Tabulata. - In Teichert, C. (ed.). Treatise on Invertebrate Paleontology, Part F, Coelenterata, Supplement 1: 762 pp. (2 volumes), Boulder/Colorado (Geological Society of America), Lawrence/Kansas (University Press).

Il'ina, T. G. 1970. K voprosu o proiskhozhdenii shestiluchevykh korallov. [On the problem of origin of Hexacorals]. - In Il'ina, T. G. (ed.). Mezozoyskie korally SSSR. Trudy 2. Vsesoyuznogo simpoziuma po izucheniyu iskopaemykh korallov SSSR, 4. - Institut Geologii i Geofiziki, Sibirskoe Otdelenie, Akademiya Nauk SSSR: 6-14, Izdatel'stvo Nauka, Moskva.

- 1984. Istoricheskoe razvitie korallov. Podotryad Polycoeliina. [Historical development of corals, suborder Polycoeliina]. - Trudy Paleontologicheskogo Instituta, Akademiya Nauk SSSR 198: $1-184$.

Ivanovskiy, A. B. 1960. Sistematicheskoe polozhenie i stratigraficheskoe rasprostranenie roda Paterophyllum Počta. [The systematical position and the stratigraphical distribution of the genus Paterophyllum Počta]. - Trudy Sibirskogo Nauchno-Issledovatel'skogo Instituta Geologii, Geofiziki i Mineral'nogo Syr'ya (SNIIGGIMS) 8 (seriya neftyanaya geologiya; Materialy po paleontologii i stratigrafii Zapadnoy Sibiri): 89-91.

- 1963. Rugozy ordovika i silura Sibirskoy platformy. [Rugosa from the Ordovician and Silurian of the Siberian platform]. - Institut Geologii i Geofiziki, Akademiya Nauk SSSR, Sibirskoe Otdelenie, 1-160, Izdatel'stvo Akademii Nauk SSSR, Moskva.

- 1965. Drevneyshie rugozy. [The oldest Rugosa]. - Institut Geologii i Geofiziki, Akademiya Nauk SSSR, Sibirskoe Otdelenie, 1-152, Izdatel'stvo Nauka, Moskva.

- 1970. O sistematicheskom polozhenii nekotorykh rugoz ordovika i silura. [On Systematical Position of some Ordovician and Silurian Rugosa]. - Geologiya i Geofizika 1970 (2): $120-122$.

- 1976. Ukazatel' rodov rugoz. [Index of rugose coral genera]. - Trudy, Institut Geologii i Geofiziki, Akademiya Nauk SSSR, Sibirskoe Otdelenie 217: 1-256.

Ivanovskiy, A. B. \& Shurygina, M. V. 1975. Reviziya rugoz Urala (V. Lonsdayl, 1845; F. N. Chernyshev, 1885, 1893; E. D. Soshkina, 1937; T. V. Nikolaeva, 1949). [A revision of the rugose corals of Ural Mts.]. - Trudy Instituta Geologii i Geofiziki, Akademiya Nauk SSSR, Sibirskoe Otdelenie 218: 1-66.

Koker, E. M. J. 1924. Anthozoa uit het Perm van het eiland Timor. I. Zaphrentidae, Plerophyllidae, Cystiphyllidae, Amphiastraeidae. - Jaarboek van het Mijnwezen in Nederlandsch Oost-Indie, 1922 Verhandelingen 51: 1-50.

Kolosváry, G. 1958. Trias-Madreporarien aus der Zeit vor dem ungarischen Ladinikum. - Acta Universitatis Szegediensis, Acta Biologica, nova series 4 (3-4): 237-244.

- 1966. Über Triaskorallenfauna Ungarns. - Acta Universitatis Szegediensis, Acta Biologica, nova series 12 (3-4): 125-137.

Krasnov, E. V. 1970. Filogenez i problema tselostnosti gruppy Scleractinia. [Phylogenesis and the problem of the wholness of Scleractinia groups]. - In Il'ina, T. G. (ed.). Mezozoyskie korally SSSR. Trudy 2. Vsesoyuznogo simpoziuma po izucheniyu iskopaemykh korallov SSSR, 4. Institut Geologii i Geofiziki, Sibirskoe Otdelenie, Akademiya Nauk SSSR: 15-40, Izdatel'stvo Nauka, Moskva.

Krueger, H.-H. 1993. Erinnerungen an das Ehepaar Neben. Geschiebekunde aktuell 9 (1): 15-16.

Kullmann, J. 1965. Rugose Korallen der Cephalopodenfazies und ihre Verbreitung im Devon des südöstlichen Kantabrischen Gebirges (Nordspanien). - Akademie der Wissenschaften und der Literatur [in Mainz], Abhandlungen der mathematisch-naturwissenschaftliche Klasse 1965 (2): 33-168.

Lambe, L. M. 1901. A revision of the genera and species of Canadian Palaeozoic corals. The Madreporaria Aporosa and the Madreporaria Rugosa. - Contributions to Cana- dian Palaeontology (Geological Survey of Canada) 4 (2): I-II, 97-197.

Latypov, Yu. Ya. 1978. Rugosa. - In Volkova, K. N., Latypov, Yu. Ya. \& Khayznikova, K. B (eds). Ordovik i silur Yuzhnogo Verkhoyan'ya. [Ordovician and Silurian of the South Verchoyan]. - Trudy Instituta Geologii i Geofiziki, Akademiya Nauk SSSR, Sibirskoe Otdelenie, Institut Biologii Morya, Dal'nevostochnyy Nauchnyy Tsentr 381: 69-98, 170-172, 195-207.

Laub, R. S. 1983. The Silurian Coral Biostratigraphy of New York. - In Sorauf, J. E. \& Oliver, W. A. jr. (eds). Silurian and Devonian Corals and Stromatoporoids of New York. [Guidebook] - International Association for the Study of Fossil Cnidaria; Fourth International Symposium on Fossil Cnidaria, August 1983: I-III, 9-34; Washington.

Liao Wei-hua \& Cai Tu-ci 1987. Sequence of Devonian rugose coral assemblages from northern Xinjiang. - Acta Palaeontologica Sinica 26 (6): 689-707.

Lindström, G. 1882. Silurische Korallen aus Nord-Russland und Sibirien. - Bihang till Kongliga Svenska VetenskapsAkademiens Handlingar 6 (18): 1-23.

McLean, R. A. 1976. Aspects of the Silurian Rugose Coral fauna of the Yass region, New South Wales. - Proceedings of the Linnean Society of New South Wales 100 (3): 179-194.

Menning, M., Gast, R., Hagdorn, H., Käding, K.-Ch., Simon, T., Szurlies, M. \& Nitsch, E. 2006. Zeitskala für Perm und Trias in der Stratigraphischen Tabelle von Deutschland 2002, zyklostratigraphische Kalibrierung von höherer Dyas und Germanischer Trias und Alter der Stufen Roadium bis Rhaetium 2005. - In Menning, M. \& Hendrich, A. (eds). Erläuterungen zur Stratigraphischen Tabelle von Deutschland 2005 (ESTD 2005). - Newsletters on Stratigraphy 41 (1-3): 173-210.

Milne-Edwards, H. \& Haime, J. 1850-1855. A Monograph of the British Fossil Corals. - The Palaeontographical Society [Monographs]: I-LXXXV, 1-322 [Part 1, 1850: I-LXXXV, 1-72, pls 1-11 (vol. 3-7); Part 2, 1851: 73-146, pls 12-30 (vol. 5-12); Part 3, 1852: 147-210, pls 31-46 (vol. 6-14); Part 4, 1853: 211-244, pls 47-56 (vol. 7-20); Part 5, 1855: 245-322, pls 57-72 (vol. 8-29, dated 1854)].

Montanaro-Gallitelli, E. 1976. Hexanthiniaria, a new Ordo of Zoantharia (Anthozoa, Coelenterata). - Bollettino della Società Paleontologica Italiana 14 (1): 21-25 (dated 1975).

Morycowa, E. 1988. Middle Triassic Scleractinia from the Cracow-Silesia region, Poland. - Acta Palaeontologica Polonica 33 (2): 91-121.

Münster, G. 1839. Der Chiton priscus und einige andere seltene Versteinerungen aus der Uebergangs-Formation. Beiträge zur Petrefacten-Kunde 1: $38-44$, Buchner, Bayreuth.

Neben, W. \& Krueger, H.-H. 1971. Fossilien ordovicischer Geschiebe. - Staringia (Nederlandse Geologische Verenigung) 1: [1-7], pls 1-50.

- 1973. Fossilien ordovicischer und silurischer Geschiebe. Staringia (Nederlandse Geologische Verenigung) 2: [1-10], pls 51-109.

- 1979. Fossilien kambrischer, ordovicischer und silurischer Geschiebe. - Staringia (Nederlandse Geologische Verenigung) 5: 1-63, pls 110-164.

Neuman, B. E. E. 1988. Some aspects of life strategies of Early palaeozoic rugose corals. - Lethaia 21 (2): 97-114.

Nicholson, H. A. 1889. [Invertebrates]. - In Nicholson, H. A. \& Lydekker, R. (eds). A manual of Palaeontology for the use of students. - 3rd edition, vol. 1, I-XVIII, 885 pp., Edinburgh - W. Blackwood \& Sons; London.

Odin, G. S. 1994. Geological time scale (1994). - Compte Rendu de l'Académie des Sciences 318 (2): 59-71.

Oliver, W. A. jr. 1989. An Early Middle Devonian Coral Faunule from the Needmore Shale in South-Central Pennsylvania and Adjacent Areas of West Virginia and Virginia. Bulletin, U.S. Geological Survey 1860-C: I-III, 1-11. 
Oliver, W. A. jr. \& Galle, A. 1971. Rugose corals from the upper Konĕprusy Limestone (Lower Devonian) in Bohemia. - Sborník Geologických Věd, Paleontologie, řada P 14: $35-106$

Oliver, W. A. jr. \& Sorauf, J. E. 1983. The Devonian Rugose Corals of New York. - In Sorauf, J. E. \& Oliver, W. A. jr. (eds). Silurian and Devonian Corals and Stromatoporoids of New York. [Guidebook] - International Association for the Study of Fossil Cnidaria; Fourth International Symposium on Fossil Cnidaria, August 1983: I-III, 35-51, Wahington.

Picard, E. 1916. Mitteilungen über den Muschelkalk bei Rüdersdorf. - Jahrbuch der Königlich Preussischen Geologischen Landesanstalt 191435 (2): 366-372.

Philip, G. M. 1962. The palaeontology and stratigraphy of the Siluro-Devonian sediments of the Tyers area, Gippsland, Victoria. - Proceedings of the Royal Society of Victoria 75 (2): 123-246.

Počta, P. 1902. Anthozoaires et Alcyonaires. - In Barrande, J. Système Silurien du Centre de la Bohême. Partie I. Recherches Paléontologiques. VIII.2: I-VIII, 1-347, pls 20-118, Prague (éditée par le Musée Bohême).

Raab, O. 1907. Neue Beobachtungen aus dem Rüdersdorfer Muschelkalk und Diluvium. - Jahrbuch der Königlich Preussischen Geologischen Landesanstalt und Bergakademie 1904 25: 205-217.

Roniewicz, E., Stolarski, J. \& Russo, A. 2003. Triassic Scleractinia: heterogenous organisms with Paleozoic roots. Berichte des Institutes für Geologie und Paläontologie der Karl-Franzens-Universität Graz 7 ( $9^{\text {th }}$ International Symposium on Fossil Cnidaria and Porifera, Abstracts): 92.

Safford, J. M. 1869. Geology of Tennessee: I-XI, 1-550, S. C. Mercer, Nashville.

Schindewolf, O. H. 1931. On the genotype and septal development of the coral genus Petraia Münster. - The Quarterly Journal of the Geological Society of London 87 (4): 630-649.

- 1942. Zur Kenntnis der Polycoelien und Plerophyllen. Eine Studie über den Bau der „Tetrakorallen“ und ihre Beziehungen $\mathrm{zu}$ den Madreporarien. - Abhandlungen des Reichsamts für Bodenforschung, Neue Folge 204: $1-324$.

- 1943. Spekulation oder Tatsachenforschung? Bemerkungen zur Beurteilung meiner Abhandlung über die Polycoelien und Plerophyllen. - Berichte des Reichsamts für Bodenforschung Wien 1943 (7): 101-110.

- 1952. Korallen aus dem Karbon (Namur) des oberschlesischen Steinkohlen-Beckens. - Akademie der Wissenschaften und der Literatur [in Mainz], Abhandlungen der mathematisch-naturwissenschaftlichen Klasse 1952 (4): 143-227.

Schmidt, M. 1928. Die Lebewelt unserer Trias. 461 pp., Hohenlohe'sche Buchhandlung Ferdinand Rau, Öhringen.

Schroeder, H. 1914. Wirbeltiere der Rüdersdorfer Trias. Abhandlungen der Königlich Preussischen Geologischen Landesanstalt, Neue Folge 65: 1-99.

Scrutton, C. T. 1997. The Palaeozoic corals, I. Origins and relationships. - Proceedings of the Yorkshire Geological Society 51 (3): 177-208.

Simpson, G. B. 1900. Preliminary descriptions of new genera of Paleozoic Rugose corals. - Bulletin of the New York State Museum 8 (39): 199-222.

Smith, S. 1930. Some Valentian Corals from Shropshire and Montgomeryshire, with a Note on a New Stromatoporoid. The Quarterly Journal of the Geological Society of London 86 (2): 291-330.

Soshkina, E. D. 1937. Korally verkhnego silura i nizhnego devona vostochnogo i zapadnogo sklonov Urala. [Corals of the Upper Silurian and Lower Devonian of the eastern and western slopes of the Urals]. - Trudy Paleozoologicheskogo Instituta, Akademiya Nauk SSSR 6 (4): 1155 .
- 1952. Opredelitel' devonskikh chetyrekhluchevykh korallov. [Determination book of Devonian tetracorals]. Trudy Paleontologicheskogo Instituta, Akademiya Nauk SSSR 39: $1-127$.

- 1955. Korally. [Corals]. - In Ivanova, E. A., Soshkina, E. D., Astrova, G. G. \& Ivanova, V. A. (eds). Fauna ordovika i gotlandiya nizhnego techeniya r. Podkamennoy Tunguski, ee ekologiya i stratigraficheskoe znachenie. [Ordovician and Gotlandian fauna of the lower section of the r. Podkamennaya Tunguska, its ecology and stratigraphical significance]. - Trudy Paleontologicheskogo Instituta, Akademiya Nauk SSSR 56: 93-196.

Soshkina, E. D., Dobrolyubova, T. A. \& Kabakovich, N. V. 1962. Podklass Tetracoralla. Chetyrekhluchevye korally (Rugosa). - In Orlov, Yu. A. (ed.). Osnovy Paleontologii. [vol. II, ed. Sokolov, B. S.]. Gubki, arkheotsiaty, kishechnopolostnye, cervi: 286-356, Izdatel'stvo Akademii Nauk SSSR, Moskva.

Spasskiy, N. Ya. 1960. Devonskie chetyrekhluchevye korally Rudnogo Altaya. [Devonian Tetracorals from the Rudny Altai]. - Paleontologicheskoe obosnovanie stratigrafii paleozoya Rudnogo Altaya (Altayskiy Gorno-Metallurgicheskiy Nauchno-Issledovatel'skiy Institut Akademii Nauk Kazakhskoy SSR, Vsesoyuznyy Aerogeologicheskiy Trest Ministerstva Geologii i Okhrany Nedr SSSR) 3: 1-143, Gosgeoltekhizdat, Moskva.

- 1965. Osnovy sistematiki devonskikh chetyrekhluchevykh korallov. [Fundamentals of the systematics of Devonian tetracorals]. - In Sokolov, B. S. \& Ivanovskiy, A. B. (eds). Rugozy paleozoya SSSR (Trudy 1. Vsesoyuznogo simpoziuma po izucheniyu iskopaemykh korallov SSSR, vypusk 3). - Institut Geologii i Geofiziki, Akademiya Nauk SSSR, Sibirskoe Otdelenie: 80-90, Izdatel'stvo Nauka Moskva.

- 1971. Tetracorallia. - In Dubatolov, V. N. \& Spasskiy, N. Ya. (eds). Devonskie korally Dzhungaro-Balkhashskoy provintsii. [Devonian corals of the Dzhungaria-Balkhash province]. - Trudy, Institut Geologii i Geofiziki, Akademiya Nauk SSSR, Sibirskoe Otdelenie 74: 1-132.

- 1977. Devonskie rugozy SSSR (sistematika, stratigraficheskoe i geograficheskoe znachenie). [Devonian Rugosa of the USSR (systematics, stratigraphical and geographical importance]. - Ministerstvo Vysshevo i Srednego Spetsial'nogo Obrazovaniya RSFSR: 285 pp.; Izdatel'stvo Universiteta, Leningrad.

Stanley, G. D. 2003. The evolution of modern corals and their early history. - Earth Science Reviews 60: 195-225.

Stumm, E. C. 1949. Revision of the families and genera of the Devonian tetracorals. - Memoir, Geological Society of America 40: I-VIII, 1-92.

Sutherland, P. K. 1965. Henryhouse Rugose Corals. - Bulletin, Oklahoma Geological Survey 109: 1-92.

Swartz, F. M. 1929. The Helderberg Group of parts of West Virginia and Virginia. - Professional Paper, [United States] Geological Survey 158-C: 27-75.

Sytova, V. A. 1975. Rugozy pogranichnykh ordoviksko-siluriyskikh otlozheniy Podolii. [The Rugose corals of the Ordovician-Silurian boundary beds of Podolia]. - In Balashov, E. G. (ed.). Fauna pogranichnykh ordoviksko-siluriyskikh otlozheniy Podolii - Voprosy Paleontologii (Leningradskiy Universitet) 7: 11-24, 150-153.

Talent, J. A., Gratsianova, R. T. \& Yolkin, E. A. 2001. Latest Silurian (Pridoli) to middle Devonian (Givetian) of the Asia-Australia hemisphere: rationalization of brachiopod taxa and faunal lists; stratigraphic correlation chart. Courier Forschungsinstitut Senckenberg 236: 1-221.

Vaughan, T. W. \& Wells, J. W. 1943. Revision of the suborders, families, and genera of the Scleractinia. - Special Papers, Geological Society of America 44: I-XV, 1-363.

Verrill, A. E. 1865. Classification of polyps (Extract condensed from a Synopsis of the Polypi of the North Pacific Exploring Expedition, under Captains Ringgold and Rodgers, U.S.N.). [Part I]. - Proceedings of the Essex Insti- 
tute, Communications read before the Essex Institute, 1864-1865 4: 145-152.

Volz, W. 1896. Die Korallenfauna der Trias. II. Die Korallen der Schichten von St. Cassian in Süd-Tirol. - Palaeontographica 43 (1-2): 1-124.

Wedekind, R. 1927. Die Zoantharia Rugosa von Gotland (bes. Nordgotland). - Sveriges Geologiska Undersökning, serie Ca, Avhandlingar och Uppsatser i 4:0 19: 1-95.

Weissermel, W. 1925. Die Korallen des deutschen Muschelkalks. I. Unterer Muschelkalk. - Jahrbuch der Preußischen Geologischen Landesanstalt, für 1925 46: 1-33 (volume dated 1926, reprint dated 1925).

- 1927. Die Umbildung der Rugosen in Hexacorallen. Sitzungsberichte der Preußischen Geologischen Landesanstalt 2: 1-17.

- 1928. Die Korallen des deutschen Muschelkalks II. Oberer Muschelkalk. - Jahrbuch der Preußischen Geologischen Landesanstalt, 1928 49: 224-238.

- 1936. Aus der Form- und Stammesgeschichte der Korallen. - Sitzungsberichte der Gesellschaft Naturforschender Freunde [Berlin] 1936 (4-7): 219-244.

- 1941. Korallen aus dem Unterdevon des östlichen und westlichen Schiefergebirges Thüringens (Die Korallen des thüringischen Devons. Teil 2). - Zeitschrift der Deutschen Geologischen Gesellschaft 93 (4-5): 163-212.

- 1943a. [Review of] Schindewolf, O. H.: Zur Kenntnis der Polycoelien und Plerophyllen. - Zentralblatt für Mineralogie, Geologie und Paläontologie, Teil IV, Paläontologie 18 (1): 94-99.

- 1943b. In eigener Sache. - Berichte Reichsamt Bodenforschung [Wien] 1943 (7): 110-112.

Wells, J. W. 1956. Scleractinia. - In Moore, R. C. (ed.). Treatise on Invertebrate Paleontology, Part F, Coelenterata: I-XX, 1-498 (F328-444), Geological Society of America, New York; University of Kansas Press, Lawrence/Kansas.

Weyer, D. 1972. Rugosa (Anthozoa) mit biformem Tabularium. - Jahrbuch für Geologie (Zentrales Geologisches Institut Berlin), for 1968 4: 439-463.

- 1973. Über Protozaphrentis Yü, 1957 (Anthozoa Rugosa, Mittelordoviz). - Paläontologische Abhandlungen, Abteilung A, Paläozoologie 4 (4): 695-706, Berlin.

- 1974. Zur Kenntnis von Rhegmaphyllum Wedekind, 1927 (Anthozoa, Rugosa; baltoskandisches Silur). - Zeitschrift für Geologische Wissenschaften 2 (2): 157-183.

- 1978. Neue Sutherlandiniinae (Rugosa) aus dem skandinavischen Silur und aus dem thüringischen Devon. Freiberger Forschungshefte, C 342: 91-116.

- 1980. Das silurisch-devonische Rugosa-Genus Petraia Münster 1839. - Freiberger Forschungshefte, C 357: 25-41.

- 1984. Korallen im Paläozoikum von Thüringen. - Hallesches Jahrbuch für Geowissenschaften 9: 5-33.

- 2001. Muenstraia, ein neues Rugosa-Genus (Anthozoa) aus dem Obersilur und Unterdevon. - Mitteilungen aus dem Museum für Naturkunde in Berlin, Geowissenschaftliche Reihe 4: 71-82.

Yu Chang-min \& Liao Wei-hua 1978. Lower Devonian rugose corals from Alengchu of Lijiang, northwestern Yunnan. Acta Palaeontologica Sinica 17 (3): 245-266.

Zheltonogova, V. A. 1965. Znachenie rugoz dlya stratigrafii silura Gornogo Altaya i Salaira. [Significance of Rugosa for the stratigraphy of the Silurian in the Gorny Altai and Salair]. - In Sokolov, B. S. \& Ivanovskiy, A. B. (eds). Rugozy paleozoya SSSR (Trudy 1. Vsesoyuznogo simpoziuma po izucheniyu iskopaemykh korallov SSSR, vypusk 3). Institut Geologii i Geofiziki, Akademiya Nauk SSSR, Sibirskoe Otdelenie: 33-44, Izdatel'stvo Nauka, Moskva.

Zeng Cai-lin \& Cai Tu-ci 1983. Coelenterata (Rugosa). - In Geological Institute of Geological Bureau of Xinjiang, Geological Survey Department of Petroleum Bureau of Xinjiang (eds). Paleontological Atlas of Northwest China; Xinjiang Uygur Autonomous Region. Part II. Late Palaeozoic I-XIII: 113-216, 684-704; Geological Publishing House, Beijing.

\section{Appendix - the stratigraphical error}

The locality data of the holotype of Triadophyllum posthumum Weissermel, 1925 were given as Rüdersdorf, the well known region of Muschelkalk quarries SE of Berlin. The specimen was collected in 1888 and became part of a famous private collection of local Triassic fossils (chemist Oskar Raab in Berlin) which was acquired nearly in 1909 by the Royal Prussian Geological Survey; there Schroeder (1914) described part of the Reptilia including the new-named Nothosaurus raabi. The horizon was declared to be the upper part of the Lower Muschelkalk, the local Schaumkalk sequence, currently renamed Rüdersdorf Formation by Bachmann et al. (1999: 86, fig. 2). Weissermel (1925: 29) even referred to a special series of beds corresponding to the "Terebratula Zone/Bank" of the classical Muschelkalk lithostratigraphy in Thuringia (now the middle part of the Jena Formation, Pelsonian); he was following the advice of his colleague Edmund Picard (1876-1949), renowned specialist in the Triassic, in 1916 also publishing about the Rüdersdorf locality, and preparing since about 1912 a palaeontological monograph of the invertebrate faunas from Rüdersdorf, which remained unfinished and unpublished.

The "Schaumkalk sequence" of Rüdersdorf differs significantly from the normal "Wellenkalk" facies in Thuringia and correlates with a level from the base of the "Oolith Bank" to the top of the "Schaumkalk Bank" (Dockter et al. 1980: 957, tab. 6). That means Pelsonian and basal Illyrian of the Tethyan realm.

The only other coral recorded from the Rüdersdorf locality is the genuinelly Triassic Pamiroseris silesiaca (Beyrich, 1852) - Beyrich (1852: 216); Eck (1863: 408; 1865: 139, pl. 1/3a-b; 1879: 256), Weissermel (1925: 4, pl.1/1), classified by these authors still as Thamnastraea (Fig. 7). The precise level within the "Schaumkalk" (now Rüdersdorf Formation) remains unknown. Distribution data in Upper Silesia (Poland) indicate Pelsonian and lower Illyrian (middle to upper Anisian - Morycowa 1988: 94).

Weissermel (1925: 29) also mentioned notes written on the coral slab by the former owner Oskar Raab (concerning the collecting date and the precise horizon): they would exclude any idea about a possible interpretation of the specimen being perhaps in a Silurian erratic boulder. This clearly indicates that there had been such discussions (thinking of a Silurian age of the coral), at least with some of his colleagues of the staff within the Prussian Geological Survey, or perhaps also with some Berlin members of the active society of amateurs collecting fossils from Pleistocene erratic boulders that society published the first volume of her new journal "Zeitschrift für Geschiebeforschung" in 1925. 
Here, I was able to get further oral information in 1965 from Walter Neben (1901-1979), an outstanding "Geschiebesammler" living in Berlin, amateur collector of fossils from Pleistocene erratic boulders (especially Palaeozoic) in the far environments of Berlin, well known among such circles for his three publications (Neben \& Krueger 1971, 1973, 1979), and honoured in a short obituary (Krueger 1993). He told me the story as known in 1925 among both palaeontologically and biostratigraphically interested amateurs of that "Geschiebesammler" kind. They were convinced of the undoubted Silurian age of this problematical "Rüdersdorf coral" on the basis of the lithology and preservation, and by traditional knowledge about the collecting methods of Oskar Raab, the "finder" of Triadophyllum posthumum Weissermel, 1925. Most of the fossils of the now famous Raab collection had been collected not by himself, but by the workers of the Rüdersdorf quarry, being well paid for this, for example with one tub of beer for one tub of fossils. Such relatively high financial stimulations motivated these workers to take nearly every fossil, even from the Pleistocene moraine covering the Triassic Muschelkalk beds.

Unfortunately, I could not detect an obituary notice about Oskar Raab. There is no record in the relevant "Biographisch-literarisches Handwörterbuch der exakten Naturwissenschaften" of J. C. Poggendorff. Directories of the city of Berlin cite a chemist (or sometimes technician) Oskar Raab in the period 1890-1910; this registration disappeared after 1911, obviously due to his death in 1909 or 1910, and corresponding to the probable date 1909 for the acquisition of his collections by the Royal Prussian Geological Survey (as indicated on some of the labels of the Raab collection in Berlin). There is only one geological publication by Raab himself (1907). Surprisingly, even Paul Dienst (1881-1939), the long standing chief of the museum department in the Prussian Geological Survey, apparently had only restricted knowledge about the collector Raab, when (1933) using a wrong first name Otto instead of Oskar.

Around 1942, there was clear further evidence for serious doubts in Berlin about the presumed Triassic age of Triadophyllum. The well known ana- lysis of Rugosan - Scleractinian relationships by Schindewolf (1942) did not mention the taxon; this would be really strange considering a possible connecting link between the two discussed Anthozoan groups, whereas all the many other relevant cases during the long history of coral research are correctly and critically cited. According to oral information again of Walter Neben in 1965, Otto Heinrich Schindewolf (1896-1971) was well aware of the real Silurian age (as a Pleistocene erratic boulder) and preferred to keep silent instead to blame his colleague Waldemar Weissermel (1870-1943) who was still working (as a pensioner) in the same former Prussian Geological Survey. It is noteworthy to see that Weissermel (1943a) too did not refer to the "forgotten" Triadophyllum in a critical review of the Schindewolf (1942) monograph, which caused a further dispute (Schindewolf 1943, Weissermel 1943b) also not touching that "Triassic" phantom perhaps meanwhile he himself had some resignation in this affair.

The holotype specimen of Triadophyllum posthumum Weissermel, 1925 is preserved in Berlin (Prussian Geological Survey - see Dienst \& Gothan 1928: 29; later between 1945 and 1989 mainly named Zentrales Geologisches Institut; today Bundesanstalt für Geologie und Rohstoffe, Außenstelle Berlin). In 1925, preparation by etching with potassium hydrate had freed the coral from the limestone slab and its calice from covering sediment; at present only the coral specimen has survived through the war, and the sediment block seems to be lost (thus excluding any micropalaeontological control of the Silurian age). The coral holotype itself was displaced in 1944 from the exhibition part of the museum rooms in the Prussian Geological Survey (then just renamed Reichsamt für Bodenforschung) to a secure underground depot in a mining gallery of the Rüdersdorf quarries near Berlin, jointly with most other type materials of the two outstanding palaeontological institutions of Berlin. There it was found by the Red Army and transported to the Soviet Union in 1945, after which it was returned to Berlin in 1957 from Leningrad (together with other valuable, mainly art collections, especially the paintings of the famous Dresden picture-gallery). 